
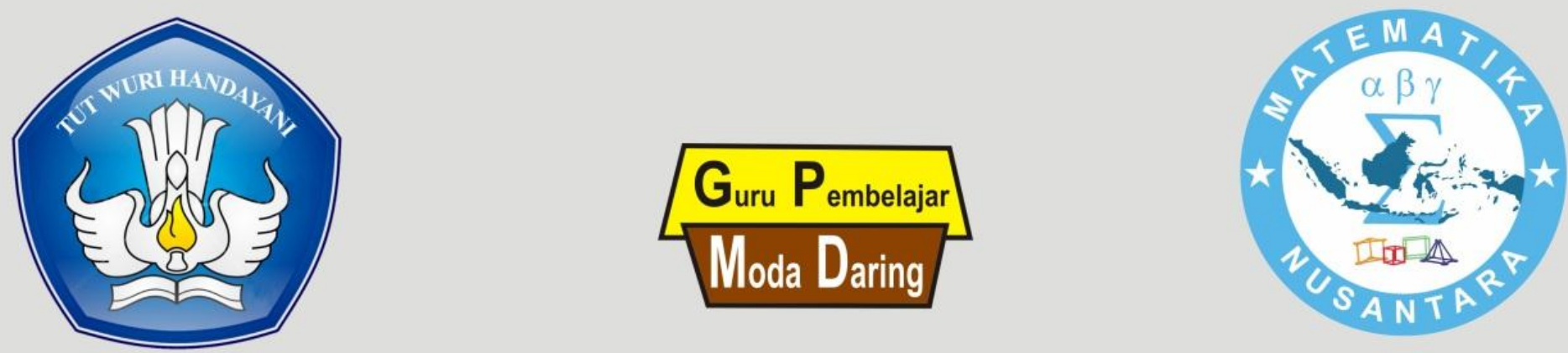

\title{
Penguatan Konsep
}

\section{Garis dan Sudut}

\section{Mata Pelajaran Matematika SMP}

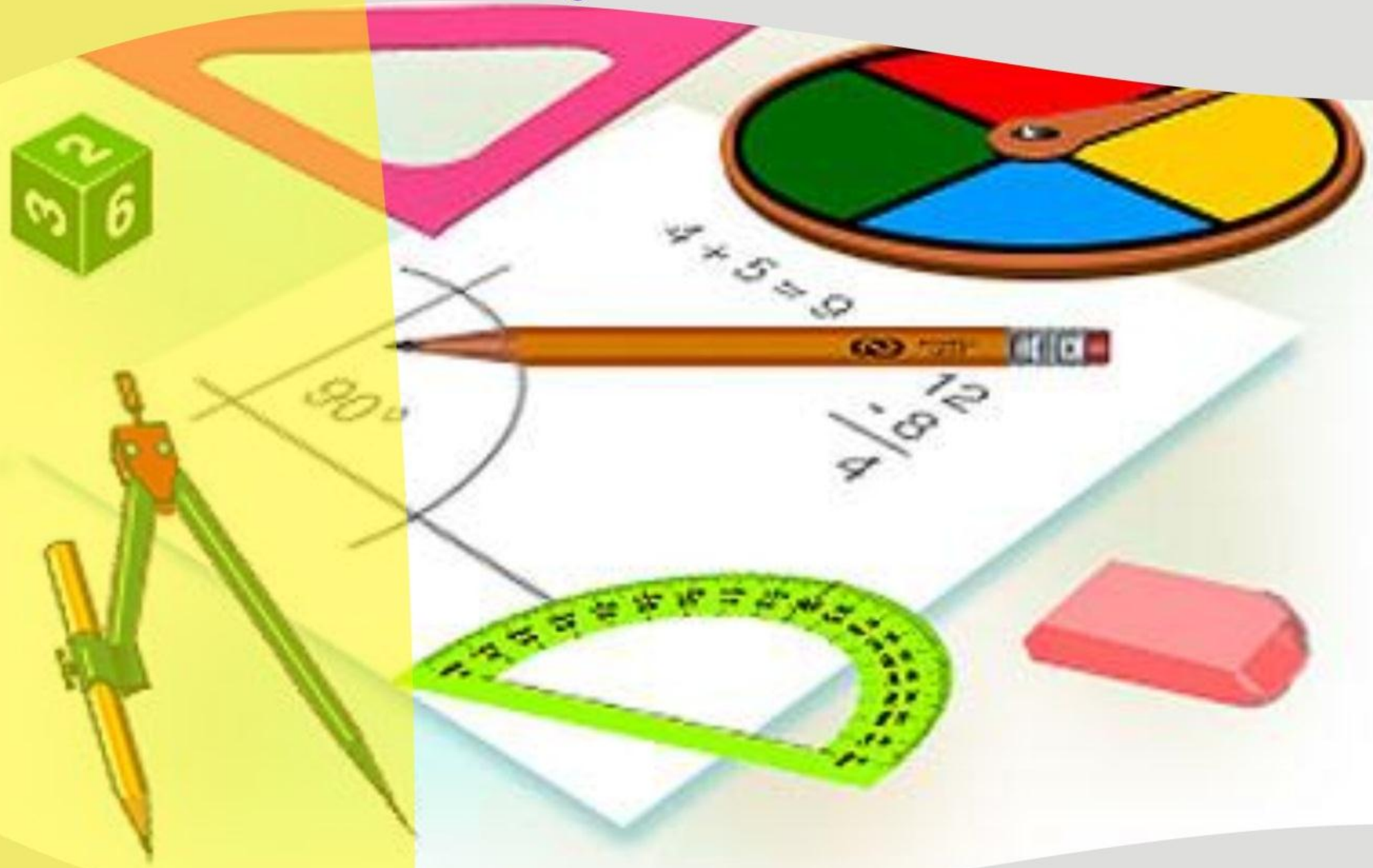

Penulis: Mohammad Tohir, S.Pd

Bahan Ajar

Matematika Nusantara 


\section{DAFTAR ISI}

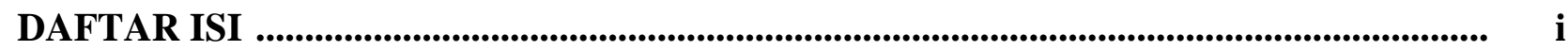

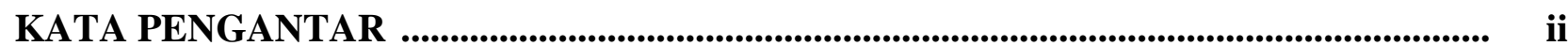

Kegiatan Pembelajaran 2 ....................................................................................................................... 1

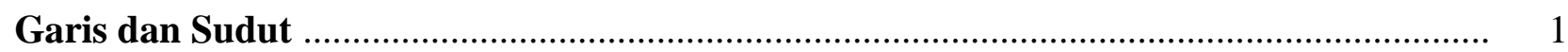

A. Tujuan ...................................................................................................................................... 1

B. Indikator Pencapaian Kompetensi ................................................................................. 1

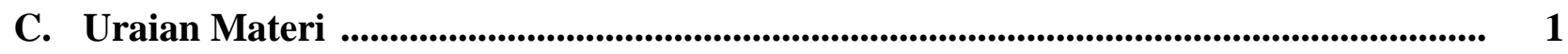

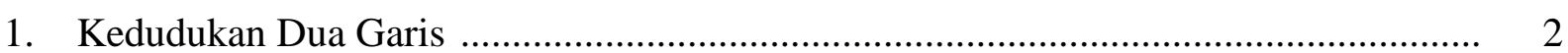

2. Titik Tengah Ruas Garis dan Bisektor ................................................................. 3

3. Pengertian Sudut dan Macamnya …...................................................................... 4

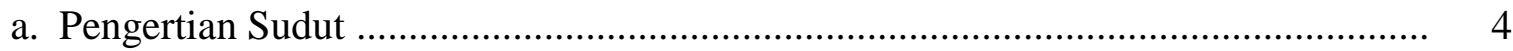

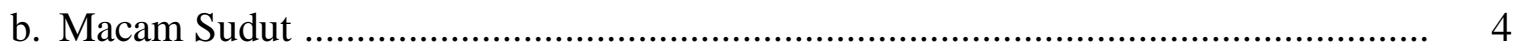

c. Satuan Ukuran Sudut …….............................................................................. 5

d. Bisektor Sudut (garis bagi) ............................................................................. 7

e. Relasi Dua Sudut ..................................................................................... 8

f. Hubungan Sudut-sudut pada Dua Garis Sejajar ............................................... 8

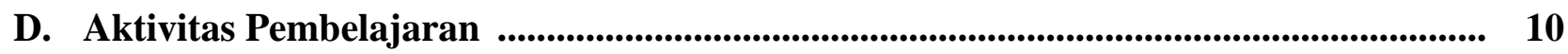

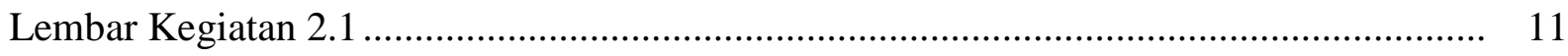

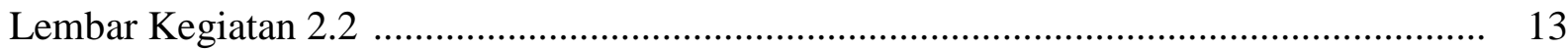

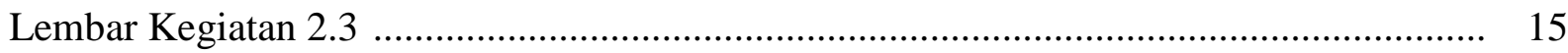

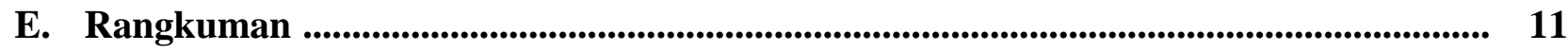

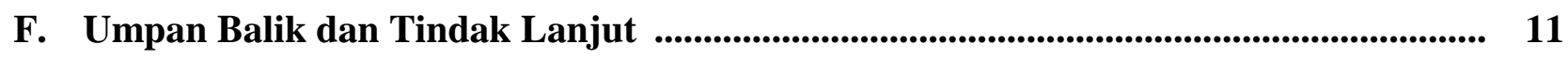

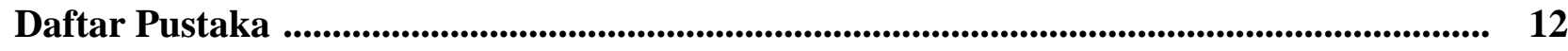




\section{KATA PENGANTAR}

Puji dan syukur penulis panjatkan kepada Allah SWT. yang telah memberikan kesehatan dan nikmat sehingga penulis mampu menyelesaikan Modul ini. Penulis juga mengucapkan terima kasih kepada pengurus Matematika Nusantara yang telah memfasilitasi teman-temen guru dalam rangka pendalaman konsep pada kelompok kompetensi $\mathrm{F}$ untuk profesional melalui moda daring. Kegiatan ini akan dilaksanakan tanggal 8 - 26 Agustus 2017

Penulis telah berupaya semaksimal mungkin dalam terselesinya modul ini, namun menyadari mungkin masih ada kelemahan baik dari segi isi maupun penulisan dan juga tata bahasa. Penulis mengharapkan saran dan kritik yang bersifat membangun dari pembaca demi perbaikan isi modul ini.

Modul ini berisi tentang materi pokok garis dan sudut yang perlu diketahui oleh semua pihak, terutama bafi peserta moda daring. Hal ini terkait dalam pelaksanaan Pendidikan dan Pelatihan Dalam Jaringan Penguatan Konsep Dasar Matematika . Selanjutnya modul ini disampaikan kepada seluruh peserta dan panitia sebagai bahan ajar dalam melaksanakan kegiatan moda daring. Setelah munguasai modul ini diharapan peserta mampu secara optimal dalam menggunakan pemahamannya ketika menghadapi UKG dan proses belajaran mangajar di kelas.

Kami berharap dengan terselenggaranya Pendidikan dan Pelatihan ini dapat meningkatkan kompetensi pedagogik dan profesional guru matematika Indonesia. Akhirnya kami ucapkan selamat mengikuti kegiatan ini, semoga mendapatkan manfaat yang optimal.

Akhir kata penulis ucapkan, semoga modul ini bermanfaat dan dapat digunakan untuk pendamping belajar sebaik-baiknya. Saran dan kritik membangun sangat penulis harapkan untuk perbaikan penulisan modul lebih lanjut.

Jember, 07 Agustus 2017

Penulis,

Mohammad Tohir, S.Pd

MN.17.001707 


\section{Kegiatan Pembelajaran 2}

\section{Garis dan Sudut}

\section{A. Tujuan}

Dalam kegiatan pembelajaran ini, Anda akan mempelajari hubungan dua garis, titik tengah ruas garis dan bisektor, pengertian sudut dan macamnya, serta transversal dua garis melalui berbagai aktivitas yang ada dalam kegiatan pembelajaran ini. Tujuan kegiatan pembelajaran ini yaitu agar setelah melakukan aktivitas dan mengerjakan tugas dalam modul ini baik secara mandiri maupun kelompok, Anda mampu mengidentifikasi aksioma, definisi, dan teorema yang berlaku pada suatu pernyataan geometris khususnya pada garis dan sudut. Selain itu, diharapkan peserta dapat mengembangkan soal penilaian berbasis kelas sesuai kompetensi dasar siswa yang terkait materi tersebut.

\section{B. Indikator Pencapaian Kompetensi}

Peserta dapat.

1. Mengidentifikasi macam kedudukan dua garis.

2. Menjelaskan ciri-ciri sudut berdasarkan definisinya

3. Mengkonversi besar sudut dalam satuan derajat, radian dan gradian

4. Menentukan hubungan pasangan sudut pada bidang datar

\section{Uraian Materi}

Garis dan sudut adalah dua objek berbeda di dalam geometri. Jika garis termasuk pengertian pangkal atau primitif term, maka sudut bukan pengertian pangkal. Dalam hal ini sudut dapat didefinisikan melalui pengertian garis.

Apa yang disebut garis adalah objek tak didefinisikan yang telah dimaklumi dan dipahami kebanyakan orang. Ia hanya memiliki satu dimensi, yang memiliki dua arah bertolak belakang dan memanjang sejauh tak hingga di kedua arah tsb. Apa yang kita sebut sinar adalah bagian dari garis, yang tidak lain memiliki satu arah untuk memanjang dan satu titik ujung (yang disebut titik pangkal sinar). Sementara apa yang disebut segmen garis atau ruas garis adalah bagian garis atau sinar yang memiliki 2 titik ujung (disebut juga titik batas ruas garis).

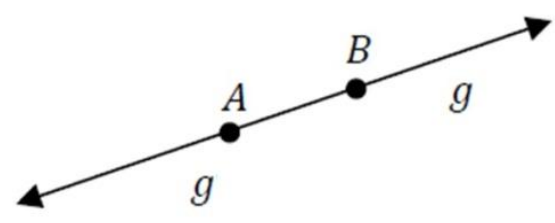


Garis $g$ dapat juga dinamakan garis $\overleftrightarrow{A B}$. Sementara sinar yang bertitik pangkal di $A$ dinamakan sinar $\overrightarrow{A B}$ (dengan tanda panah di atas huruf $A B$ mengarah ke kanan). Ruas garis yang dibatasi oleh $A$ dan $B$ secara sederhana ditulis dengan $\overline{A B}$. Ini adalah kesepakatan yng umum dipakai dalam matematika. Namun dalam beberapa literatur bisa saja membuat aturan untuk lebih menyederhakan cara penulisan simbol garis, sinar, dan ruas garis.

\section{Kedudukan Dua Garis}

Hubungan dua garis bergantung pada dimensi yang dibicarakan. Hubungan dua garis dalam dimensi dua (bidang datar) akan berbeda hubungannya di dimensi tiga (ruang).

Berikut ini hubungan dua garis di bidang datar, yaitu jika kedua garis terletak pada bidang yang sama.

Tabel 2.1 Kedudukan Dua Garis

\begin{tabular}{|c|c|c|}
\hline No. & $\begin{array}{c}\text { Gambar Dua Garis } \\
\text { Terletak Pada Bidang } \alpha\end{array}$ & Katerangan \\
\hline \multirow{2}{*}{1.} & $\alpha$ & $\begin{array}{l}\text { Garis } h \text { dan } g \text { merupakan dua garis } \\
\text { yang saling berpotongan di titik T. } \\
\text { - Garis } h \text { dan } g \text { membentuk } 4 \text { (empat) } \\
\text { sinar garis yang bersekutu pada satu } \\
\text { titik awal, yaitu titik } T \text {. }\end{array}$ \\
\hline & $\alpha$ & $\begin{array}{l}\text { - Garis } h \text { dan } g \text { merupakan dua garis } \\
\text { yang saling berpotongan tegak lurus di } \\
\text { titik T. } \\
\text { - Garis } h \text { dan } g \text { membentuk } 4 \text { (empat) } \\
\text { sinar garis yang bersekutu pada satu } \\
\text { titik awal, yaitu titik } T \text {. }\end{array}$ \\
\hline 2. & $\alpha$ & $\begin{array}{l}\text { - Garis } h \text { dan } g \text { merupakan dua garis } \\
\text { yang sejajar } \\
\text { - } \\
\text { Ruas garis TO sepanjang } a \mathrm{~cm}(a \in N) \\
\text { merupakan jarak terpendek yang } \\
\text { menghubungkan kedua garis } h \text { dan } g\end{array}$ \\
\hline 3. & $\alpha$ & $\begin{array}{l}\text { - Garis } h \text { dan } g \text { merupakan dua garis } \\
\text { yang berhimpit } \\
\text { - Garis } h \text { dan } g \text { pada hakekatnya } \\
\text { merupakan sebuah garis yang mewakili } \\
\text { dua jenis garis berbeda } \\
\text { - Ruas garis } T O \text { memotong di kedua } \\
\text { garis } h \text { dan } g\end{array}$ \\
\hline
\end{tabular}




\section{Keterangan:}

Notasi dari dua garis berpotongan adalah $\times$

Notasi dari dua garis berpotongan tegak lurus adalah $\perp$

Notasi dari dua garis sejajar adalah \|

Hubungan dua garis pada ruang macamnya hampir sama dengan hubungan pada bidang datar, kecuali ditambah satu hubungan lagi yang disebut hubungan 2 garis yang saling bersilangan. Dua garis dikatakan bersilangan, jika kedua garis tidak memiliki titik persekutuan dan tidak sejajar.Secara lebih ringkas, dua garis dikatakan bersilangan jika kedua garis tidak terletak pada satu bidang datar.

Contoh sederhana pada kubus $A B C D . E F G H$. Garis yang memuat rusuk $A B$ bersilangan dengan garis yang memuat rusuk $F G$.

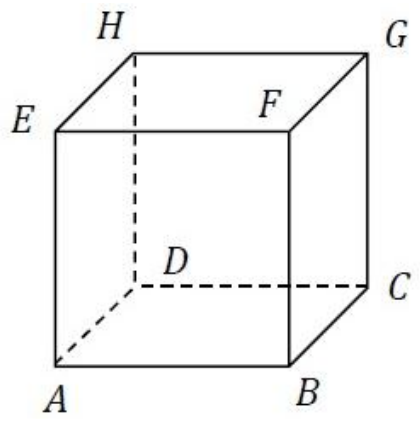

Gambar 2.1 Ruas garis pada kubus

\section{Titik Tengah Ruas Garis dan Bisektor}

Terkait dengan ruas garis, terdapat beberapa konsep di bawah ini.

a. Titik tengah suatu ruas garis adalah suatu titik yang memisahkan/membagi ruas garis tersebut menjadi dua ruas garis yang sama ukurannya (kongruen).

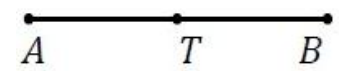

T titik tengah $\overline{A B} \Rightarrow \overline{A T} \cong \overline{T B}, A T=T B$

b. Bisektor dari suatu ruas garis adalah garis yang memisahkan/membagi ruas garis tersebut menjadi dua ruas garis yang sama ukurannya (kongruen)

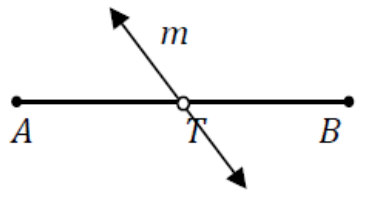

M bisektor $\overline{A B} \Rightarrow \overline{A T} \cong \overline{T B}, A T=T B$ 


\section{Pengertian Sudut dan Macamnya}

a. Pengertian Sudut

Sudut dapat didefinisikan bermacam-macam. Sudut dapat didefinisikan sebagai bangun geometri yang dibentuk oleh dua sinar dengan titik pangkal yang berimpit. Definisi ini bersifat statis. Besar sudut yang diperhatikan adalah besar sudut terkecil yang terbentuk.

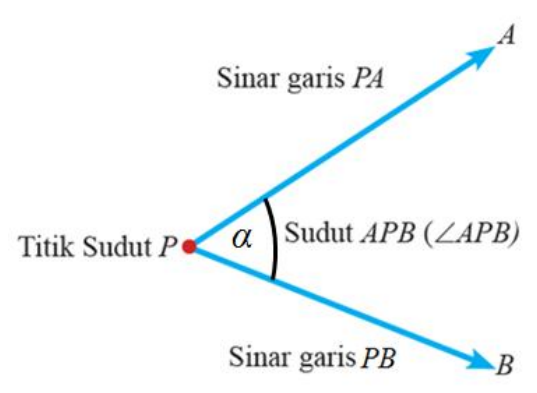

Gambar 2.2 Sudut yang terbentuk oleh dua sinar garis

Suatu sudut terbentuk dari perpotongan dua sinar garis yang berpotongan tepat di satu titik, sehingga titik potongnya disebut dengan titik sudut.

Nama suatu sudut dapat berupa simbol $\alpha, \beta$, dll, atau berdasarkan titik titik yang melalui garis yang berpotongan tersebut. Biasanya, satuan sudut dinyatakan dalam dua jenis, yaitu derajat $\left({ }^{\circ}\right)$ dan radian (rad). $\angle A P B$ bisa juga disebut $\angle P$, dan besar sudut $\mathrm{P}$ dilambangkan dengan $m \angle P$.

b. Macam Sudut

Dengan memperhatikan besar putaran yang terbentuk dari awal sampai satu putaran penuh, sudut dapat diklasifikasikan/didefinisikan sebagai berikut.

Tabel 2.2 Macam-macam sudut

\begin{tabular}{|c|l|l|}
\hline No. & Gambar & Keterangan \\
\hline 1. & & $\begin{array}{l}\text { Sudut lancip, besarnya kurang dari } \\
\text { seperempat putaran penuh. } \\
\text { Atau ukuran sudut lancip sebesar antara } 0^{\circ} \\
\text { dan } 90^{\circ}\end{array}$ \\
\hline 2. & $\begin{array}{l}\text { Sudut siku-siku, besarnya seperempat } \\
\text { putaran penuh } \\
\text { Atau ukuran sudut siku-siku sebesar 90 } 90^{\circ}\end{array}$ \\
\hline
\end{tabular}




\begin{tabular}{|c|l|l|}
\hline No. & Kambar & Keterangan \\
\hline 3. & $\begin{array}{l}\text { Sudut tumpul, besarnya lebih dari } \\
\text { seperempat putaran, kurang dari setengah } \\
\text { putaran. } \\
\text { - Atau ukuran sudut tumpul sebesar antara } \\
90^{\circ} \text { dan } 180^{\circ}\end{array}$ \\
\hline 4. & $\begin{array}{l}\text { Sudut lurus, besarnya setengah putaran } \\
\text { penuh }\end{array}$ \\
\hline 5. & \begin{tabular}{l} 
Atau ukuran sudut lurus sebesar 180 \\
\hline 6.
\end{tabular} & $\begin{array}{l}\text { Sudut refleks, besarnya lebih dari setengah } \\
\text { putaran, kurang dari satu putaran penuh. }\end{array}$ \\
\hline
\end{tabular}

c. Satuan Ukuran Sudut

Tiga macam satuan sudut yang banyak digunakan: derajat, radian, dan gradian.

1) Satuan derajat

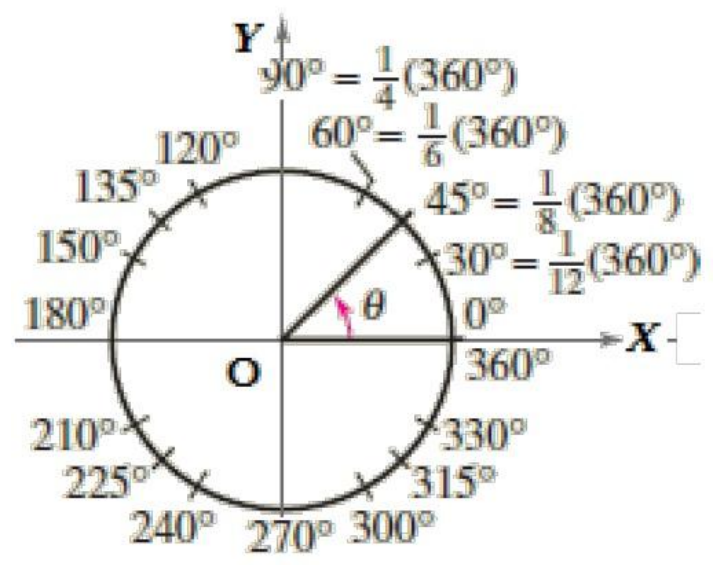

Gambar 2.3 Ukuran derajad

Bila pada sebuah lingkaran digambar jari-jari sedemikian sehingga membaginya menjadi 360 bagian yang sama, maka sudut antara setiap dua jari-jari yang berurutan besarnya dinamakan 1 (satu) derajat, dilambangkan $\mathbf{1}^{\circ}$. 
Demikianlah maka $1^{\circ}$ adalah ukuran sudut yang besarnya sepertigaratus enampuluh putaran penuh. Satu derajat dibagi menjadi 60 sama besar, masingmasing dinamakan 1 menit (1'). Satu menit dibagi menjadi 60 sama besar, masing-masing 1 detik ( $\left(1^{\prime \prime}\right)$.

Jadi pada ukuran sudut ini berlaku: $\mathbf{1}^{\circ}=\mathbf{6 0}^{\prime}=\mathbf{3 6 0 0}{ }^{\prime \prime}$

(satu derajat sama dengan 60 menit, sama dengan 3600 detik).

Pada perhitungan, sering juga digunakan satuan campuran. Dalam derajat dilambangkan dengan sistem desimal, misalnya $31^{\circ} .30^{\prime} .15^{\prime \prime}$ dimana

$$
31^{\circ} \cdot 30^{\prime} \cdot 15^{\prime \prime}=31^{\circ}+\left(\frac{30}{60}\right)^{\circ}+\left(\frac{15}{3600}\right)^{\circ}=31,504167^{\circ}
$$

2) Satuan radian

Sebelum kita memahami hubungan derajat dengan radian, mari pelajari teori mengenai radian berikut.

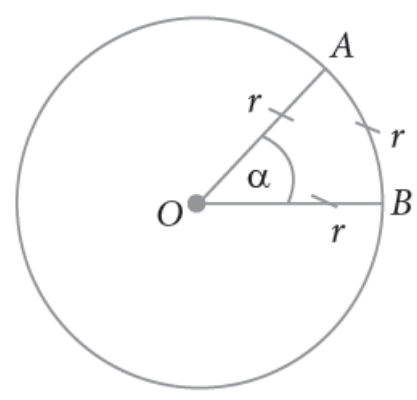

Gambar 2.4 Ukuran radian

Satu radian diartikan sebagai besar ukuran sudut pusat $\alpha$ yang panjang busurnya sama dengan jari-jari, perhatikan Gambar 2.4. Jika $\angle A O B=\alpha$ dan $A B=O A=$ $O B$, maka

$$
\propto=\frac{\widehat{A B}}{r}=1 \text { radian }
$$

Jika panjang busur tidak sama dengan $r$, maka cara menentukan besar sudut tersebut dalam satuan radian dapat dihitung menggunakan perbandingan:

$$
\angle A O B=\frac{\widehat{A B}}{r}=1 \mathrm{rad} \text {. }
$$

Lebih lanjut, dapat dikatakan bahwa hubungan satuan derajat dengan satuan radian, adalah 1 putaran sama dengan $2 \pi \mathrm{rad}$. Oleh karena itu, berlaku

$$
360^{\circ}=2 \pi \mathrm{rad} \text { atau } 1^{\circ}=\frac{\pi}{180^{\circ}} \text { atau } 1 \mathrm{rad}=\frac{180^{\circ}}{\pi} \cong 57,3^{\circ}
$$


Kemudian, berikut cara mengkonversinya.

$>$ Komversi $a$ derajad ke radian dengan mengalikan $a \times \frac{\pi}{180^{\circ}}$ Misalkan, $45^{\circ} \times\left(\frac{\pi}{180^{\circ}}\right) \mathrm{rad}=\frac{\pi}{4} \mathrm{rad}$.

$>$ Komversi a radian ke derajad dengan mengalikan $a \times \frac{180^{\circ}}{\pi}$ Misalkan, $\frac{3}{2} \pi \mathrm{rad}=\frac{3}{2} \pi \times\left(\frac{180^{\circ}}{\pi}\right)=270^{\circ}$.

3) Satuan gradian

Satuan yang satu ini jarang muncul di buku pelajaran, tetapi selalu hadir dalam kalkulator saintifik. Dalam kalkulator dikenal dengan simbol GRAD. Untuk satuan derajatd engan $D E G$ dan satuan radian dengan $R A D$. Satuan sudut ini banyak dipergunakan untuk kepentingan yang terkait dengan ilmu geologi. Busur sebesar 1 gradian di permukaan bumi sepanjang lingkaran equator kirakira sama dengan jarak $100 \mathrm{~km}$.

Dalam satuan gradian, satu putaran penuh diukur sebagai 400 gradian, yang disingkat 400 grad atau $400^{\mathrm{g}}$.

Jadi, $400^{\mathrm{g}}=360^{\circ}$ sehingga $10^{\mathrm{g}}=9^{\circ}$ atau $1^{\mathrm{g}}=0,9^{\circ}$.

d. Bisektor Sudut (garis bagi)

Bisektor sudut (garis bagi) adalah sinar garis yang titik pangkalnya berimpit dengan titik sudut tersebut dan dengan masing-masing sisi sudut tersebut membentuk dua sudut yang kongruen.

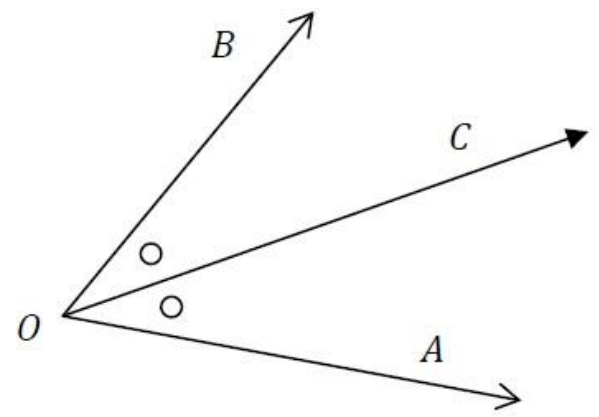

Sinar $O C$ pada gambar di atas merupakan bisektor sudut $A O B$. 
e. Relasi Dua Sudut

Dengan memperhatikan dua sudut yang terbentuk dari dua garis atau lebih di satu titik pusat, maka, dua sudut tersbut dapat diklasifikasikan/didefinisikan sebagai berikut.

Tabel 2.3 Macam-macam sudut

\begin{tabular}{|c|c|c|}
\hline No. & Gambar & Keterangan \\
\hline 1. & & $\begin{array}{l}\text { Sudut } a^{\circ} \text { dan } b^{\circ} \text { merupakan dua sudut yang } \\
\text { terbentuk dari satu titik sudut dan salah satu } \\
\text { kakinya bersekutu pada garis } l \text {, dan kaki-kaki } \\
\text { lainnya berada di garis } k \text { dan } m \text {. }\end{array}$ \\
\hline 2. & & $\begin{array}{l}\text { Sudut } c^{\circ} \text { dan } d^{\circ} \text { merupakan dua sudut yang } \\
\text { terbentuk oleh perpotongan garis } k \text { dan } l \text { di titik } \\
T \text {, dimana masing-masing kedua sudut tersebut } \\
\text { tidak memiliki kaki sudut yang sama. }\end{array}$ \\
\hline 3. & & $\begin{array}{l}\text { Sudut } e^{\circ} \text { dan } f^{\circ} \text { merupakan dua sudut yang } \\
\text { saling berpenyiku (berkomplemen), dimana } \\
\text { jumlah besar } e^{\circ} \text { dan } f^{\circ} \text { sama dengan } 90^{\circ} \text {. }\end{array}$ \\
\hline 4. & & $\begin{array}{l}\text { Sudut } g^{\circ} \text { dan } h^{\circ} \text { merupakan dua sudut yang } \\
\text { saling berpelurus (bersuplemen), dimana } \\
\text { jumlah besar } g^{\circ} \text { dan } h^{\circ} \text { sama dengan } 180^{\circ} \text {. }\end{array}$ \\
\hline
\end{tabular}

f. Hubungan Sudut-sudut pada Dua Garis Sejajar

Dengan memperhatikan suatu garis yang memototong pada dua garis yang saling sejajar, maka sudut-sudut tersbut dapat diklasifikasikan/didefinisikan sebagai berikut.

Tabel 2.4 Hubungan sudut-sudut pada dua garis sejajar

\begin{tabular}{|c|c|c|}
\hline No. & Gambar & Keterangan \\
\hline 1. & 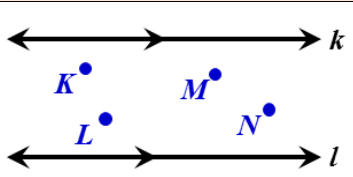 & $\begin{array}{l}\text { Titik-titik } K, L, M, \text { dan } N \text { merupakan titik-titik } \\
\text { interior garis } k \text { dan } l \text { atau titik-titik yang berada di } \\
\text { daerah dalam garis } k \text { dan } l\end{array}$ \\
\hline
\end{tabular}




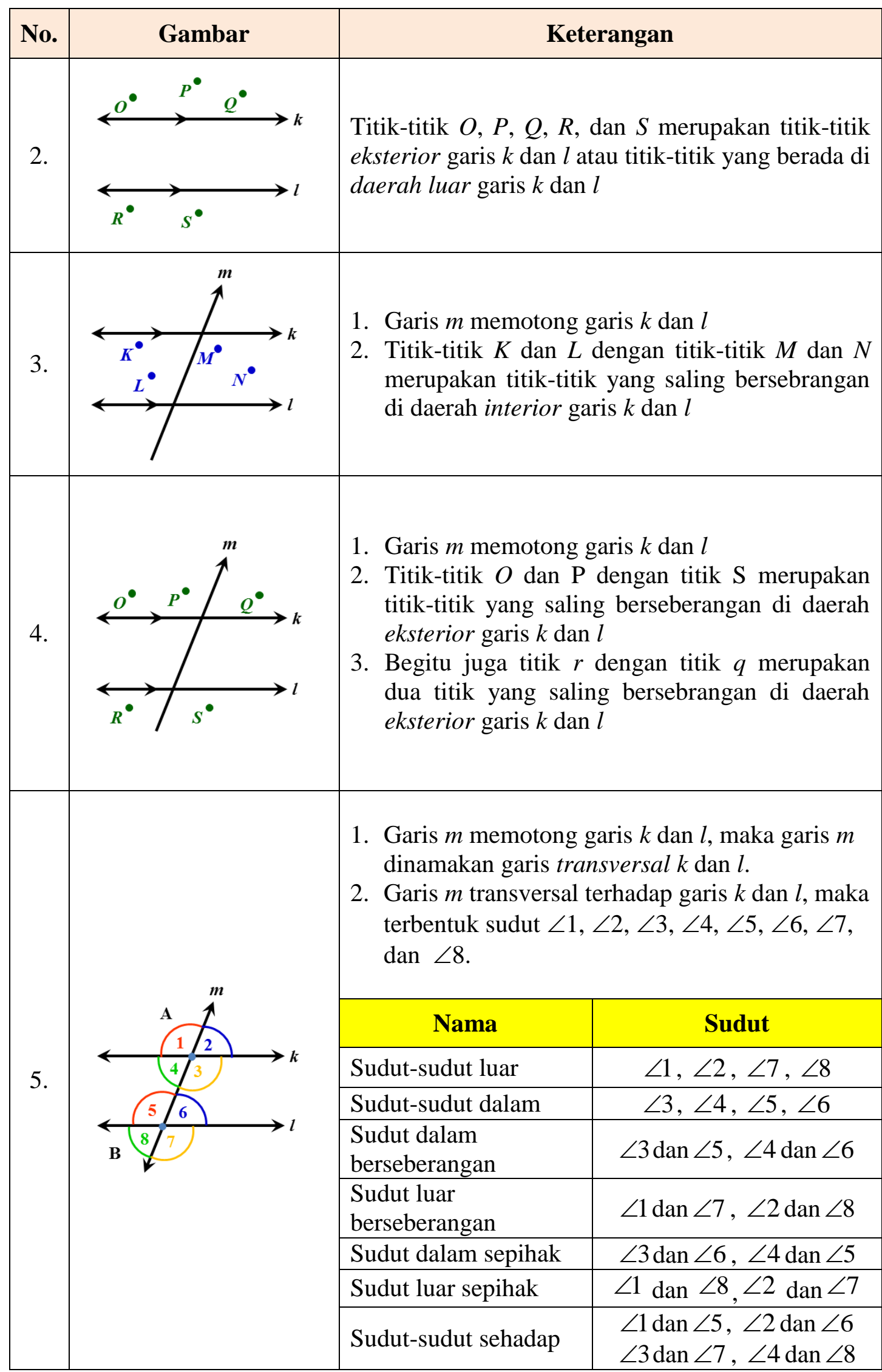

Dalam pembelajaran garis dan sudut, guru dapat pula menyisipkan nilai-nilai karakter terutama karakter yang identik dengan matematik. Salah satunya yaitu nilai karakter konsisten terhadap kaidah/konsensus yang berlaku secara umum atau disepakati bersama. Misalnya saja 
dalam memberikan simbol terhadap nama sudut, penulisan besar sudut, pemberian istilah hubungan dua garis atau sudut, dan sebagainya. Selain itu, karakter positif yang dapat dikembangkan antara lain kritis dalam menganalisis suatu konsep atau pernyataan untuk mengembangkan suatu kebenaran baru. Misalnya guru dapat memberikan pertanyaan kepada siswa ada berapakah banyak titik persekutuan jika dua garis diketahui minimal memiliki 2 titik persekutuan. Siswa dapat diminta untuk membuktikan tersebut dengan berdasarkan hasil analisisnya. Dengan memberikan stimulus yang tepat, siswa dapat mengembangkan karakter mengutamakan berpikir logis dalam menjawab atau melakukan suatu hal, teliti dalam menjawab permasalahan, memiliki keingintahuan yang tinggi, dan sebagainya.

\section{Aktivitas Pembelajaran}

Dengan cara mandiri atau berkelompok (disarankan 3 hingga 5 orang), lakukanlah aktivitas yang berikut ini. Tulislah hasil diskusi ke dalam Lembar Kegiatan yang ada.

1. Pelajarilah bagian uraian materi dengan seksama. Beri penekanan atau garis bawah, poinpoin materi yang Anda anggap penting.

2. Jawablah beberapa pertanyaan terkait garis dan sudut sesuai lembar kegiatan yang ada, di bagian bawah. Berusahalah dengan keras dan kreatif.

3. Diskusikanlah dalam kelompok Anda. Rujuklah ke dalam uraian materi dan bila perlu dengan sumber pustaka di luar yang terpecaya. Bekerjasamalah dengan semangat gotong royong.

4. Paparkan dalam presentasi di kelas, baik sebagian maupun keseluruhan kelompok. Lakukan hal tersebut secara santun namun komunikatif. Hindari debat kusir.

5. Dengan fasilitasi nara sumber, diskusikanlah hasil-hasil paparan yang sudah dilakukan, dan temukan resume dari kegiatan belajar ini. 


\section{E. Rangkuman}

Sudut dapat dipandang sebagai bentukan dari sebuah sinar yang diputar, sehingga besar sudut juga dapat ditentukan oleh berapa besar putaran yan terjadi. Untuk satuannya, dikenal satuan derajat dan satuan radian. Hubungan dua sudut juga dapat ditentukan berdasarkan jumlah ukurannya. Relasi dua garis dapat berpotongan maupun sejajar (dalam kasus ekstrim keduanya berimpit). Terdapat banyak relasi khusus beberapa garis yang ditentukan oleh besar sudut-sudut yang terbentuk.

\section{F. Umpan Balik dan Tindak Lanjut}

Periksalah pemahaman Anda dengan materi yang disajikan dalam modul ini, serta hasil pengerjaan aktivitas pembelajaran dan latihan/tugas dengan kunci jawaban. Untuk membantu dalam mengevaluasi hasil pengerjaan aktivitas pembelajaran, berikut petunjuk pengerjaannya.

Pada aktivitas dengan LEMBAR KEGIATAN 2.1, Anda dapat menentukan hubungan pasangan sudut dengan melihat uraian materi pada subbagian relasi dua sudut dan transversal dua garis. Sementara untuk nomor 2, Anda dapat melakukan peragaan sederhana untuk mendapatkan perubahan yang terjadi, misal menggunakan 3 buah lidi atau sesuatu yang lain yang mewakili ke-3 buah garis. Lakukan sambil dicermati menggunakan penalaran logis.

Pada aktivitas dengan LEMBAR KEGIATAN 2.2., berikut petunjuk sederhananya. (Silakan dikembangkan juga argumentasinya). Karakteristik sudut berdasarkan definisi1 memiliki ruang lingkup yang lebih sempit dibanding sudut berdasarkan definisi 2. Untuk soal no.2, Anda harus memperhatikan hal tsb sebagai kesetaraan satuan. Nomor selanjutnya, silakan melihat uraian materi untuk melihat bagaimana pengerjaan yang seharusnya.

Pada aktivitas dengan LEMBAR KEGIATAN 2.3., maka Anda perlu mengkonsultasikan kebenaran dan kualitas soal dengan karakteristik soal yang baik. Dari diskusi dengan kelompok lain dan hasil paparan, juga menjadi salah satu tolok ukur, sudah sejauh mana kualitas soal yang dibuat.

Jika Anda dapat memahami sebagian besar materi dan dapat menjawab sebagian besar latihan/tugas, maka Anda dapat dianggap menguasai kompetensi yang diharapkan.Namun jika tidak atau Anda merasa masih belum optimal, silakan pelajari kembali dan diskusikan dengan teman sejawat untuk memantapkan pemahaman dan memperoleh kompetensi yang diharapkan.Setelah Anda telah dapat menguasai kompetensi pada kegiatan pembelajaran ini, silakan lanjut pada kegiatan pembelajaran berikutnya. 


\section{Daftar Pustaka}

As'ari, Abdur Rahman, Tohir, Mohammad, dkk. 2017. Matematika SMP Kelas VII. Edisi Revisi 2017: Buku Siswa. Jakarta: Pusat Kurikulum dan Perbukuan.

Krismanto, dkk. 2017. Modul Pengembangan Keprofesian Berkelanjutan Mata Pelajaran Matematika Sekolah Menengah Pertama (SMP): Kelompok Kompetensi F pada Bidang Geometri 1. Jakarta: Direktorat Pembinaan Guru Pendidikan Dasar Direktorat Jenderal Guru dan Tenaga Kependidikan Kementerian Pendidikan dan Kebudayaan.

Sinaga, Bornok, Sinambela, Pardomuan N.J.M, dkk. 2017. Matematika SMA Kelas X. Edisi Revisi 2017: Buku Siswa. Jakarta: Pusat Kurikulum dan Perbukuan. 